\title{
Hastane Okullarına Yönelik Geliştirilen Eğitici Eğitimi Programının Öğretmenler Üzerindeki Etkisi
}

\author{
Halil KAMIŞLI', Tuğba YANPAR YELKEN² ${ }^{2}$, Cenk AKAY ${ }^{3}$ \\ ${ }^{1}$ Dr, Cukurova Devlet Hastanesi, hallper77@,hotmail.com \\ 2 Prof.Dr., Mersin Üniversitesi Eğitim Fakültesi, tyanpar@mersin.edu.tr \\ 3 Yrd.Doç.Dr., Mersin Üniversitesi Eğitim Fakültesi, cenkakay35@hotmail.com
}

DOI: http://dx.doi.org/10.14582/DUZGEF.705

ÖZ

Hastanede yatan okul dönemi çocukları, hastaneye, hastalık sürecine, tekrar okula döndüğünde derslerine, arkadaşlarına uyum sağlamada fiziksel, psikolojik ve sosyal sorunlar yaşayabilmektedirler. Bu olumsuz etkileri azaltmak amaciyla dünyada ve Türkiye'de hastane okulları açılmıștır. Yapılan araștırmalarda hastane okulu öğretmenlerine yönelik bir hizmet içi eğitim programına ihtiyaç duyulduğu belirlenmiș ve bu öğretmenlere yönelik bir hizmet içi eğitim programı geliștirilmiștir. Bu arașturmada geliștirilen hizmet içi eğitim programının, öğretmenlerin akademik başarı puanlarına etkisinin belirlenmesi ile uygulama öncesi-sonrasında mesleki yeterlilik düzeylerine ve programa yönelik görüşlerinin alınması planlanmıştır. Ayrıca verilen hizmet içi eğitim programının uygulama sürecindeki etkililiğine ilişkin öğretmen düşünceleri de alınmıştır.

Tarama modelinde betimsel olan bu araștırma için hem nicel hem de nitel veriler toplanmıstur. Araştırmanın çalıșma grubunu, 2013 2014 öğretim yllında Ankara ilinde bulunan tüm hastane okullarında görev yapan 17 öğretmen oluşturmaktadır. Araştırma kapsamında, hizmet içi eğitim programına katılan öğretmenlerin, hastalık bilgisi, iletişim, ölçme-değerlendirme ve öğrenme-öğretme sürecine yönelik akademik bașarı puanlarının ve mesleki yeterlilik düzeylerine ilișkin görüșlerinin eğitim sonrası olumlu yönde artıs gösterdiği sonucuna ulaşılmıştır.

Anahtar Kelimeler: Hastane okulları, hastane sınıfı, özel eğitim

\section{The Effect of The Training of The Trainers Programme on Hospital School Teachers}

\begin{abstract}
The children staying in hospital at their school time may have psychological, physical and social problems towards hospital, illness period, lessons and friends when they go back to school. Hospital schools have been founded in order to reduce these negative aspects. The researches have revealed that an in-service training for the hospital school teachers is a lack and fort his reason a training programme has been developed. It is aimed to determine the effect of the in-service training programme on the teachers' academic achievment scores and obtain their opinions for occupational competencies and the programme itself.

Qualitative and quantitative data were collected for this survey-based research. The study group was formed of 17 teachers working at all the hospital schools in Ankara. At the end of the research, teachers' academic achievment scores for illness knowledge, communication, teaching-learning process and measurement-evaluation, have been increased positively. Furthermore they declared an affirmative progress related with their occupational competencies.
\end{abstract}

Keywords: Hospital schools, hospital class, private education

\section{GİRİŞ}

Temel eğitim süreci her çocuğun gelişimi için önemli bir yer tutmaktadır. Bu sürecin sekteye uğraması ve aksatılması çocuğun gelişimi açısından büyük sorunlar yaratabilmektedir. Çünkü okul, çocuğun yaşamındaki ilk toplumsal kurumdur. Çocuk, okula başlamakla yeni bir yaşama başlamaktadır. Yaşamında gerekli olan dersleri ve bilgileri, topluma uyum sağlaması için gerekli sosyal becerileri okulda kazanır. Çocukların dünyaya başarılı bir şekilde uyum sağlamasında ve yakın ilişkiler kurmasında olumlu bir okul deneyiminin etkili olduğu bilinmektedir (Vance \& Eiser, 2002). Fakat çocuklar zaman zaman hastalık ve hastaneye yatma durumlarından dolayı okula gidemeyebilmektedirler. Hastalık ve hastaneye yatma durumu hangi yaşta olursa olsun çocukların yaşamını olumsuz etkilediği gibi okul yaşantısını da olumsuz etkileyen bir unsurdur. Uzun süre hastanede veya evinde tedavi gören çocukların okula döndüklerinde okula uyum ve akademik performans ile ilgili sorunlar yaşadıkları görülmektedir. Çocuklarda, yaşadıkları hastalıklara bağlı olarak, fiziksel yetersizlikler meydana 
gelmekte ve bu fiziksel yetersizlikler, çocuğun spor faaliyetleri gibi fiziksel beceri gerektiren aktivitelerde akranları kadar başarılı olamamasına sebep olmaktadır. Bu başarısızlıklarda çocuklarda, düşük benlik saygısı ve aşağıllk duygusu gibi psikososyal sorunların gelişmesine neden olabilmektedir. Hatta kanser gibi bazı hastalıkların tedavisi tamamlandıktan yıllar sonra dahi çocukların fiziksel performansında ve günlük yaşam aktivitelerini sürdürmede yetersizlikler devam edebilmektedir (Ness, Mertens \& Hudson, 2005; Patenaude \& Kupst, 2005).

Hastalık ve hastanede yatma durumu, yukarda bahsedilen olumsuz fiziksel durumlara ek olarak, çocuklarda öğrenme güçlüğü, hafizada zayıflama, konuşamama gibi bazı bilişsel sorunlara neden olabilmektedir (Butler \& Mulhern, 2005; Patenaude \& Kupst, 2005; Prevatt, Heffer \& Lowe, 2000; Vannatta, Gartstein \& Short, 1998). Hasta çocuklar fiziksel görünümündeki kalıcı ya da geçici değişiklikler nedeniyle arkadaşlarının kendisiyle dalga geçebileceğini düşüncesi ile okula gitmek istemeyebilmektedirler. Bu nedenden dolayı artan okul devamsızlığı ögrenme firsatlarını azaltmakta ve akademik başarısızlığa yol açmaktadır (Eiser, Hill \& Vance, 2002; Lähteenmäki, Huostila, Hinkka \& Salmi, 2002; Prevatt ve diğerleri, 2000; Vannatta ve ark., 1998). Ayrıca hastalık durumu sadece çocukta değil, uzun dönemde ebeveyn ve kardeşler üzerinde de ruhsal ve psikososyal risklerin ortaya çıkmasına sebep olmaktadır (Fazlıŏlu, Hocaoğlu \& Sönmez, 2010; Gönener \& Görak, 2009; Sean, 2002; Aktaran: Erdogan \& Karaman, 2008).

Yapılan çalışmalar incelendiğinde çıkan ortak sonuç; çocukların, hastaneye, hastalık sürecine, tekrar okula döndüğünde derslerine, arkadaşlarına uyum sağlamada fiziksel, psikolojik ve sosyal sorunlar yaşayabileceğidir. Ayrıca buna bağlı olarak çocukta akademik başarısızlık ve duygusal çöküntü görülebileceğidir. Fakat hastalık ve hastanede yatma durumlarının, çocuğun sonraki yaşantısındaki olumsuz yönde etkileri alınabilecek önlemler ile azaltılabilir (Aktaş, 1992; Elçigil, 2007). Bunun içinde olumsuz etkileri azaltacak, çocukların hastalık süreci ve hastaneye uyumunu kolaylaştıracak, okul dönemi çocuklarının okul yaşantılarının kesintiye uğramadan hastane ortamında devam ettirebilmesini ve çocuğun kendi okuluna dönüşünde eğitiminin kesintisiz devamının sağlanmasını sağlayacak yapılanmaya ihtiyaç vardır. Bu ihtiyacın giderilmesi adına dünyada ve Türkiye'de hastane okulları açılmıştır. Bu okullar, yatarak tedavi gören ve süreğen hastalığı nedeniyle örgün eğitim kurumlarından doğrudan yararlanamayacak durumda olan ilköğretim çağındaki özel eğitime ihtiyacı olan bireylerin, eğitimlerini kesintisiz sürdürmeleri amacıyla Milli Eğitim Bakanlığı, Sağlık Bakanlığı ve üniversiteler arasında imzalanan protokole göre hastanede açılan eğitim kurumlarıdır (Baykoç, 2006). Hastanede tedavi altında bulunan çocukların eğitim hakkından faydalanmasını sağlamak ve moral düzeylerini arttırarak tedavilerine katkıda bulunmak amacı ile açılan hastane okullanı, okul dönemi çocuklarının hastanede kaldıklanı süre içinde okul yaşantılarının devam ettirilmesinde büyük rol oynayan önemli kurumlardır. Fakat literatür incelendiğinde hastane okulları ile ilgili çok fazla araştırmaya rastlanmamaktadır. Bu kadar önemli bir misyona sahip eğitim kurumları ile ilgili fazla çalışma yapılmaması bir problem olarak görülmektedir.

Hastane okullannda görev yapan öğretmenler Milli Eğitim Bakanlığı tarafindan atanmış olup, genellikle Eğitim Fakülteleri Sınıf Öğretmenliği Bölümü mezunudurlar. Öğretmenler normal okullarda uygulanan öğretim programını uygulamaktadırlar. Fakat görev yapılan ortam ve burada eğitim görecek öğrencilerin özel durumları düşünüldüğünde, bu okullarda görev yapan öğretmenlerin; alan ve pedagojik formasyon bilgisi yeterliliğine sahip olmakla birlikte sabırlı, özverili, hasta psikolojisine ilişkin öğrenciye nasıl davranması gerektiğini bilen, çeşitli hastalıklar hakkında bilgi sahibi olan kişiler olmaları gerekliliği düşünülebilir. Öğretmenlerin bu konulardaki ihtiyaçlarının giderilmesi adına dönem dönem seminerler düzenlenmiştir. Fakat en son yapılan seminer 2007 yllinda gerçekleştirilmiştir. 2007 yllindan sonra hastane okullarında göreve başlayan öğretmenlerin bu tür seminerlere katılma şansı olmamıştır. Bu açıdan bakıldığında hastane okulu öğretmenlerine yönelik bir hizmet içi eğitim programına ihtiyaç duyulduğu söylenebilir. Işıktekiner’in (2011) yaptığı çalışmada da öğretmenler hizmet içi eğitim seminerlerine ihtiyaçları olduğunu vurgulamışlardır. Fakat yapılan araştırma sonucunda, hastane okullarında çalışan öğretmenlere yönelik, onların ihtiyaçları doğrultusunda geliştirilen ve öğretmenlerin öğretim uygulamalarına ve mesleki gelişimlerine katkı sağlayacak 
bir eğitim programına rastlanmamıştır. Bu durum ise, gerek hastane okullarının gerekse bu okullarda çalışan öğretmenlerin ihtiyaçlarının giderilmesi hususunda bir eksiklik olarak görülmektedir. Bu problemin çözümüne ilişkin öncelikle Kamışlı, Yelken \& Akay'ın (2013) yaptıkları çalışma bulguları ışı̆̆ında ortaya koydukları öğretmenlerin eğitim ihtiyaçları doğrultusunda, bir hizmet içi eğitim programı geliştirilmiştir.

$\mathrm{Bu}$ araştırmada ise geliştirilen hizmet içi eğitim programının, öğretmenlerin akademik başarı puanlarına etkisinin belirlenmesi ile uygulama öncesi-sonrasında mesleki yeterlilik düzeylerine ve programa yönelik görüşlerinin alınması amaçlanmıştır. Ayrıca verilen eğitimin uygulama sürecindeki etkililiğine ilişkin öğretmen düşünceleri de alınmıştır. Bu bağlamda araştırmanın problem cümlesi; "Hastane okullarına yönelik geliştirilen hizmet içi eğitim programının öğretmenler üzerindeki etkileri nelerdir?” şeklinde oluşturulmuştur. Alt problemler ise aşağıda verilmiştir;

1. Geliştirilen hizmet içi eğitim programının öğretmenlerin akademik başarı puanlanı üzerine etkisi nasildir?

2. Öğretmenlerin, hizmet içi eğitim programının uygulanma öncesinde-sonrasında mesleki yeterlilik düzeylerine ilişkin görüşleri nasıldır?

3. Öğretmenlerin hizmet içi eğitim programına ilişkin görüşleri nelerdir?

4. Hizmet içi eğitim programının, uygulama sürecindeki etkililiğine ilişkin öğretmen düşünceleri nelerdir?

\section{YÖNTEM}

\subsection{Araştırma Modeli}

Araştırmada tarama modeli yöntemi kullanılmıştır. Karasar’a (2000) göre, tarama yöntemi geçmişte veya halen var olan bir durumu var olduğu şekliyle betimlemeyi amaçlayan bir araştırma yaklaşımıdır.

Araştırmanın nicel boyutunda, geliştirilen hizmet içi eğitim programının öğretmenlerin akademik başanı puanlarına etkisini ortaya koymak için ön-deneysel yöntem kullanılmıştr. Ön-deneysel çalışma modellerinden ise “tek grup ön-test/son-test tasarımı” kullanılmıştır. Modelin simgesel görünümü Tablo 1'de verilmiştir.

Tablo 1. Araştırma desen

\begin{tabular}{llll} 
Tablo 1. Araştırma deseni & & \\
\hline Deney Grubu & Öntestler & Uygulama & Sontestler \\
& - Akademik & Hizmet içi & - Akademik Başarı \\
& Başarı Testi & Eğitim & Testi \\
\hline
\end{tabular}

Araştırmanın nitel boyutunda ise uygulama öncesi ve sonrasında öğretmenlerin mesleki yeterlilik düzeylerine ilişkin görüşlerinin nasıl olduğunu belirlemek için mesleki yeterlilik düzeylerine ilişkin öğretmen görüş anketi kullanılmıştır. Ayııca hizmet içi eğitim programına ilişkin öğretmen görüşlerini ortaya koymak amacıyla hizmet içi eğitim programına yönelik öğretmen görüş anketi ve programın uygulama sürecindeki etkinliğine ilişkin öğretmen düşüncelerini belirlemek için ise eğitim programının etkinliğini değerlendirmeye yönelik odak görüşme formu kullanılmıştır.

\section{2. Çalışma Grubu}

Araştırmanın çalışma grubunu, 2013-2014 öğretim yılında Ankara ilinde bulunan tüm hastane okullarında görev yapan 17 öğretmen oluşturmaktadır. Ankara ilinin seçilme nedeni ise, en fazla hastane sınıfi öğretmen grubunun bu ilde yer almasıdır. Diğer bir deyişle örneklem amaçlı örneklem yöntemi ile seçilmiştir. Amaçlı örneklem derinlemesine araştırma yapabilmek amacıyla çalışmanın amacı bağlamında bilgi açısından zengin durumların seçilmesidir (Büyüköztürk, 2007).

\subsection{Veri Toplama Araçları}

Bu araştırmada veri toplamak amacıyla Akademik Başarı Testi, Mesleki Yeterlilik Düzeylerine İlişkin Öğretmen Görüş Anketi, Hizmet İçi Eğitim Programına ve Etkinliğine Yönelik Öğretmen Görüş Anketi ve Odak Görüşme Formu kullanılmıştır. Veri toplama araçlarıyla ilgili ayrıntılı bilgiler aşağıda açıklanmıştır. 


\subsubsection{Akademik Başarı Testi}

Başarı testi, geliştirilen eğitici eğitimi programının öğretmenlerin akademik başarı puanları üzerine etkisinin nasıl olduğunu belirlemek amacı ile geliştirilmiştir. Başarı testi, öğretmenlerin eğitim ihtiyaçları kapsamında oluşturulan eğitim programının hedefleri doğrultusunda oluşturulmuştur.

Eğitim programı geliştirildikten sonra, her konunun kazanımlarına (hastalık bilgisi ile ilgili; 13 hedef, 56 kazanım, iletişim konusu ile ilgili; 9 hedef, 33 kazanım, öğrenme-öğretme süreci ile ilgili; 9 hedef. 30 kazanım, ölçme ve değerlendirme ile ilgili; 2 hedef, 18 kazanım) yönelik en az üç soru olmak üzere denemelik maddeler oluşturulmuştur. Denemelik maddeler oluşturulurken konu alanı uzmanlarından test maddelerinin ölçmedeğerlendirme ilkelerine uygunluğu açısından yardım alınmıştır. Sorular alan uzmanları tarafından incelenmiş, önerilen düzeltmeler yapılmıştır. Fakat başarı testinin geçerlik ve güvenirlik çalışması yeterli öğretmen sayısı olmadığından yapılamamıştır. Çünkü Türkiye genelinde 51 hastane okulu ve her okulda 2 öğretmen vardır. Sorular ile ilgili uzman (Dahiliye, çocuk hastalıkları, iletişim, ölçme-değerlendirme ve program geliştirme uzmanları) kanısına başvurularak, oluşturulan soru havuzundan 35 maddelik çoktan seçmeli bir başarı testi oluşturulmuştur. Başarı testinde hastalık bilgisine yönelik 15 soru, iletişim ve ölçme ve değerlendirme konularına yönelik 5 soru, öğrenme ve öğretme süreçlerine yönelik ise 10 soru yer almaktadır.

\subsubsection{Mesleki Yeterlilik Düzeylerine İlişkin Öğretmen Görüş Anketi}

$\mathrm{Bu}$ anket, hizmet içi eğitim eğitimi programının uygulama öncesi ve sonrasında öğretmenlerin mesleki yeterlilik düzeylerine ilişskin görüşlerinin nasıl olduğunu belirlemek amacı ile araştırmacı tarafindan geliştirilmiştir. Geliştirilen bu anket, üçlü likert tipte (Yeterliyim- Az yeterliyim- Yetersizim) hazırlanmıştır. Anket 53 maddeden oluşmuştur.

\subsubsection{Hizmet içi Eğitim Programına Yönelik Öğretmen Görüş Anketi}

Hastane sınıfi öğretmenlerinin, gerçekleştirilen hizmet içi eğitim programına ilişkin görüşlerini belirlemek için bu anket araştırmacı tarafindan geliştirilmiştir. Bu çalışmada kullanılan anket, öğretmenlerin serbestçe cevap vermeleri istendiği için açık uçlu sorulardan oluşmaktadır. Anket 5 açık uçlu sorudan oluşmuştur.

\subsubsection{Hizmet içi Eğitim Programının Etkinliğini Değerlendirmeye Yönelik Odak Görüşme} Formu

Hastane sınıfı öğretmenlerinin, gerçekleştirilen hizmet içi eğitim programının, eğitim uygulamalanına, karşılaşılan problemlerin çözümüne, öğretmenlerin mesleki gelişimlerine sağladığ1 katkılarına yönelik görüşleri ile programın olumsuz kısımlarına yönelik önerilerini belirlemek için odak grup görüşme tekniği kullanılmıştır. Bowling'e (2002) göre odak grup görüşmesi küçük bir grupla lider arasında yapılandırılmamış görüşme ve tartışmada grup dinamiğinin etkisini kullanma, derinlemesine bilgi edinme ve düşünce üretmedir. Krueger ise (1994) odak grup görüşmesini, bireylerin düşüncelerini serbestçe söyleyebileceği bir ortamda dikkatlice planlanmış bir tartışma olarak tanımlamaktadır.

\subsection{Verilerin Analizi}

Anket sorularının analizi SPSS programı ile çözümlenmiştir. Anketle toplanan nitel veriler üzerinde frekans, yüzde analizleri yapılmıştır. Açık uçlu sorularla ve görüşmelerde elde edilen verilerin analizinde "Nitel İçerik Çözümlemesi” kullanılmıştır. Veriler üç aşamada analiz edilmiştir. Bu aşamalar; kategorilerin tanımlanması, örneklerin verilmesi ve kodlama kurallarının önceden belirlenmesidir (Mayring, 1996). Bu analiz iki uzman tarafından yapılmış ve yazıya dökülen görüşme sonuçlarını ayrı ayırı kodlanmıştır. Soruların her biri bir tema olarak düşünülmüş ve sorulara göre yapılan kodlamalardan alt temalar oluşturulmuştur. Daha sonra uzmanların arasında görüş birliği ve görüş ayrllı̆ı̆ gösteren temalar tespit edilmiştir. Görüşler arasındaki uyum oranı belirlenmiştir. Bu oran, Miles \& Huberman'ın (1994) güvenirlik formülü kullanılarak hesaplanmışır (Güvenirlik Formülü: Görüş Birliği/ Görüş Birliği+ Görüş Ayr1lı̆̆1 (40/41). Bu durumda açık uçlu anket sorularının analizi konusunda uzmanlar arasındaki güvenirlik $0.97(40 /(40+1))$ bulunmuştur. Uzmanların kodlamalarındaki benzerlik fazladır. Bu durum kodlamaların güvenilir olduğunu göstermektedir. 
Araştırmanın nicel verileri, öntest-sontest ölçümleri nedeniyle ilişkili ölçümlerden oluşmaktadır. Akademik başarı testi ön test-son test puanlarının normal dağılıp dağılmadığı incelenmiştir. Çalışma grubu 30 kişiden az olduğundan dolayı normal dağılım özelliklerini belirlemek için "Shapiro-Wilk Testi” uygulanmıştır. Puanlar normal dağllım göstermediği için "Wilcoxon Signed Rank" testi uygulanmıştır. Her bir veri ile ilgili ölçümler aşağıda ayrıntılı olarak verilmiştir.

\subsection{Hizmet içi Eğitim Programı ve Uygulanması}

Kamışlı, Yelken \& Akay'n (2013) yaptıkları çalışma bulgulanı ışı̆̆ında ortaya koydukları öğretmenlerin eğitim ihtiyaçları doğrultusunda geliştirilen hizmet içi eğitim programı, hastalık bilgisi ile ilgili; 13 hedef, 56 kazanım, iletişim konusu ile ilgili; 9 hedef, 33 kazanım, öğrenme-öğretme süreci ile ilgili; 9 hedef. 30 kazanım, ölçme ve değerlendirme ile ilgili; 2 hedef, 18 kazanımdan oluşmaktadır. İçerik düzenleme sürecinde modüler programlama yaklaşımı temel alınmıştır. Çünkü konular, kendi içinde anlamlı bir bütünlük oluşturmaktadır. Bir sonraki konunun öğrenilmesi için, bir önceki konuyu bilme zorunluluğu yoktur. Öğrenme-öğretme sürecinde sunuş yolu stratejisi-düz anlatım tekniği, buluş yolu stratejisi, beyin fırtınası tekniği, grup çalışması tekniği kullanılmıştır. Değerlendirme sürecinde, tanılayıcı (diyagnostik), biçimlendirici (formatif) ve düzey belirleyici (summatif) değerlendirme yapılmıştır. Hizmet içi eğitim programı Ankara Özel Eğitim ve Rehberlik binasındaki seminer salonunda gerçekleşmiştir. Eğitim beş gün (50 saat) olarak planlanmıştır ve bu şekilde gerçekleştirilmiştir.

\section{BULGULAR}

Çalışma kapsamında geliştirilen veri toplama araçları ile bulgular toplanmıştır. Elde edilen bulgular aşağıda alt problemlere göre verilmiştir.

\subsection{Araştırmanın Birinci Alt Problemine Yönelik Bulgular}

Bu bölümde geliştirilen hizmet içi eğitim programının öğretmenlerin akademik başarı puanları üzerine etkisinin nasıl olduğuna ilişkin bulgulara yer verilmiştir. Aşağıda hastalık bilgisi, iletişim, öğrenme-öğretme süreci ve ölçme değerlendirme konularına yönelik akademik başarı testi öntest-sontest puanlarına ilişkin verilere yer verilmiştir.

Çalışma grubundaki öğretmenlerin akademik başarılarına ilişkin öntest-sontest ölçümleri arasındaki farkın incelenmesi için ilişkili gruplar t-testi analizi uygulanması düşünülmüş ve bu testin varsayımları kontrol edilmiştir. Hastalık bilgisi akademik başarı puanlarına yönelik normallik testi sonuçları Tablo 2'de verilmiştir.

Tablo 2. Hastalık bilgisi akademik puanlara yönelik normallik testi

\begin{tabular}{llll}
\hline & \multicolumn{3}{l}{ Shapiro-Wilk } \\
\cline { 2 - 4 } Akademik Başarı Öntest &, 876 & $\mathbf{p}$ \\
\cline { 2 - 4 } Akademik İstatistiği & sd & 17 &, 052 \\
\hline * $<0.5$ &, 862 & 17 &, $020^{*}$ \\
\hline
\end{tabular}

Tablo 2'de görüldüğ̈ gibi varsayımların kontrolleri sırasında normal dağılım [Döntest(17)=.876, p> .05 ve Dsontest $(17)=.862, \mathrm{p}<.05]$ varsayımı sağlanamadığından Wilcoxon Testi uygulanmıştır. Wilcoxon Testi sonuçları Tablo 3’te verilmiştir.

Tablo 3. Hastalık bilgisi akademik bașarı puanlarına yönelik wilcoxon testi sonuçları

\begin{tabular}{|c|c|c|c|c|c|c|}
\hline & & $\mathbf{N}$ & S1ra Ortalamas1 & $\begin{array}{l}\text { Sira } \\
\text { Toplami }\end{array}$ & $\mathbf{Z}$ & $\mathrm{p}$ \\
\hline \multirow{3}{*}{$\begin{array}{l}\text { Akademik Başarı Sontest - } \\
\text { Akademik Başarı Öntest }\end{array}$} & Negatif Sira & 0 & 00 & ,00 & \multirow[t]{3}{*}{$-3,646$} & \multirow[t]{3}{*}{, 000} \\
\hline & Pozitif Sira & 17 & 9,00 & 153,00 & & \\
\hline & Eşit & 0 & - & - & & \\
\hline
\end{tabular}

$* \mathrm{p}<0.5$

Tablo 3'e göre çalışma grubundaki öğretmenlerin hastalık bilgisine yönelik akademik başarılarına ilişkin öntest-sontest ölçümleri sıra ortalamaları arasında anlamlı fark bulunmuştur. Bu fark, pozitif sıralar diğer ifadeyle sontest ölçümleri lehine elde edilmiştir $[\mathrm{Z}=-3.646, \mathrm{p}<.05]$. Ortalama değerlerine bakıldığında çalışma 
grubunun öntest puanlarının SSöntest $=1.53153, \quad \bar{X}_{\ddot{O} n t e s t}=9.2941 \quad$ olduğu, sontest puanlarının SSsontest $=1.05370, \bar{X}_{\text {sontest=13.1176 olduğu görülmektedir. }}$

İletişim bilgisi akademik başarı puanlarına yönelik normallik testi sonuçları Tablo 4’te verilmiştir.

Tablo 4. İletişim boyutu akademik başarı puanlarına yönelik normallik testi

\begin{tabular}{llll}
\hline & \multicolumn{3}{l}{ Shapiro-Wilk } \\
\cline { 2 - 4 } & Test İstatistiği & sd & $\mathbf{p}$ \\
\cline { 2 - 4 } Akademik Başar1 Öntest &, 591 & 17 &, $000^{*}$ \\
Akademik Başar1 Sontest &, 642 & 17 &, $000^{*}$ \\
\hline${ }^{*} \mathrm{p}<0.5$ & & &
\end{tabular}

Tablo 4'te görüldüğü gibi varsayımların kontrolleri sırasında normal dağılım [Döntest(17)=.591, p<.05 ve Dsontest $(17)=.642, \mathrm{p}<.05]$ varsayımı sağlanamadığından Wilcoxon Testi uygulanmıştır. Wilcoxon Testi sonuçları Tablo 5'te verilmiştir.

Tablo 5. İletişim boyutu akademik başarı puanlarına yönelik wilcoxon testi sonuçlanı

\begin{tabular}{lllllll}
\hline & & & Sira & Z & p \\
& & N & Sira Ortalaması & Toplami & & \\
\hline Akademik Başarı Sontest - & Negatif Sıra & 0 &, 00 &, 00 & -2.333 &, 020 \\
Akademik Başarı Öntest & Pozitif Sıra & 11 & 3,50 & 21,00 & & \\
& Eşit & 6 & - & - & \\
\hline
\end{tabular}

$*_{\mathrm{p}}<0.5$

Tablo 5’te gösterildiği gibi çalışma grubundaki öğretmenlerin iletişim bilgisi akademik başarılanna ilişkin öntest-sontest ölçümleri sıra ortalamaları arasında anlamlı fark bulunmuştur. Bu fark, pozitif sıralar diğger ifadeyle sontest ölçümleri lehine elde edilmiştir $[\mathrm{Z}=-2.333, \mathrm{p}<.05]$. Ortalama değerlerine bakıldığında çalışma grubunun öntest puanlarının SSöntest $=.72761, \quad \bar{X}_{\text {Öntest }}=4.1765$ olduğu, $\quad$ sontest puanlarının

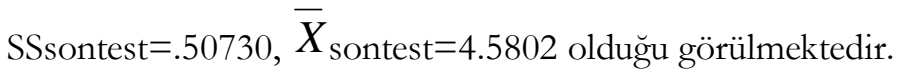

Öğrenme-öğretme akademik başarı puanlarına yönelik normallik testi sonuçları Tablo 6'da verilmiştir.

Tablo 6. Öğrenme-Öğretme boyutu akademik başarı puanlarına yönelik normallik testi

\begin{tabular}{|c|c|c|c|c|}
\hline & \multicolumn{3}{|l|}{ Shapiro-Wilk } & \\
\hline & Test İstatistiği & sd & $\mathrm{p}$ & \\
\hline Akademik Başarı Öntest & 924 & 17 & 225 & \\
\hline Akademik Başarı Sontest & 871 & 17 &, $028^{*}$ & \\
\hline
\end{tabular}
ve Dsontest $(17)=.871, \mathrm{p}<.05]$ varsayımı sağlanamadı̆̆ından Wilcoxon Testi uygulanmıştır. Wilcoxon Testi sonuçları Tablo 7'de verilmiştir.

Tablo 7. Öğrenme-Öğretme boyutu akademik başarı puanlarına yönelik wilcoxon testi sonuçları

\begin{tabular}{lllllll}
\hline & & & Sira & Z & p \\
& & N & Sira Ortalaması & Toplamı & & \\
\hline Akademik Başarı Sontest - & Negatif Sıra & 0 &, 00 &, 00 & -3.537 &, $000^{*}$ \\
Akademik Başarı Öntest & Pozitif Sıra & 16 & 8,50 & 136,00 & & \\
& Eşit & 1 & - & - & \\
\hline
\end{tabular}

${ }^{*} \mathrm{p}<0.5$
Çalışma grubundaki öğretmenlerin öğrenme-öğretme boyutu akademik başarılarına ilişkin öntest-sontest ölçümleri sıra ortalamaları arasında anlamlı fark bulunmuştur. Bu fark, pozitif sıralar diğger ifadeyle sontest ölçümleri lehine elde edilmiştir $[Z=-3.537, \mathrm{p}<.05]$. Ortalama değerlerine bakıldığında çalışma grubunun öntest puanlarının SSöntest $=1.32565, \quad \bar{X}_{\ddot{O} n t e s t}=5.4118$ olduğu, sontest puanlarının SSontest $=.78591$, $\bar{X}_{\text {sontest }}=8.3529$ olduğu görülmektedir.

Ölçme-değerlendirme akademik başarı puanlarına yönelik normallik testi sonuçları Tablo 8'de verilmiştir. 
Tablo 8. Ölçme-Değerlendirme boyutu akademik başarı puanlarına yönelik normallik testi

\begin{tabular}{|c|c|c|c|}
\hline \multirow[b]{3}{*}{ Akademik Başarı Öntest } & \multicolumn{3}{|l|}{ Shapiro-Wilk } \\
\hline & Test İstatistiği & sd & $\mathrm{p}$ \\
\hline & ,716 & 17 &, $000^{*}$ \\
\hline Akademik Başarı Sontest & 814 & 17 &, $003^{*}$ \\
\hline
\end{tabular}

Tablo 8'de görüldüğü gibi varsayımların kontrolleri sirasında normal dağılım [Döntest $(17)=.716, \mathrm{p}<.05$ ve Dsontest $(17)=.814, \mathrm{p}<.05]$ varsayımı sağlanamadı̆̆ından Wilcoxon Testi uygulanmıştır. Wilcoxon Testi sonuçları Tablo 9'da verilmiştir.

Tablo 9. Ölçme-Değerlendirme boyutu akademik başarı puanlarına yönelik wilcoxon testi sonuçları

\begin{tabular}{lllllll}
\hline & & $\mathrm{N}$ & Sira Ortalamas1 & Sira Toplamı Z & $\mathrm{p}$ \\
\hline Akademik Başarı Sontest - & Negatif Sıra & 0 &, 00 &, 00 & -3.276 &, $001 *$ \\
Akademik Başarı Öntest & Pozitif Sıra & 12 & 6,50 & 78,00 & & \\
& Eşit & 5 & - & - & & \\
\hline
\end{tabular}

${ }^{*} \mathrm{p}<0.5$
Tablo 9'da görüldüğü gibi deney grubundaki öğretmenlerin akademik başarılarına ilişkin öntest-sontest ölçümleri sıra ortalamaları arasında anlamlı fark bulunmuştur. Bu fark, pozitif sıralar diğer ifadeyle sontest ölçümleri lehine elde edilmiştir [Z=-3.276, $\mathrm{p}<$.05]. Ortalama değerlerine bakıldığında çalışma grubunun öntest

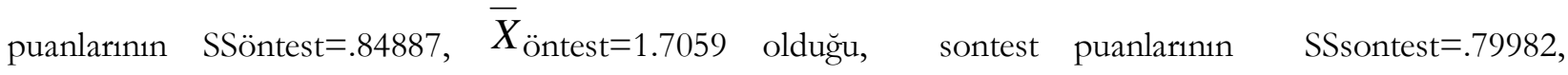

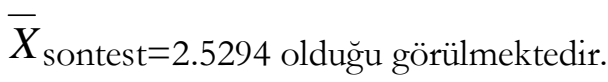

\subsection{Araştırmanın İkinci Alt Problemine Yönelik Bulgular}

Öğretmenlerin Çocuklarda Görülen Hastalıklar Hakkında Mesleki Yeterlilik Düzeylerine İlişkin Görüşlerine yönelik bulgular Tablo 10'da verilmiştir.

Tablo 10. Öğretmenlerin Çocuklarda Görülen Hastalıklar Hakkında Mesleki Yeterlilik Düzeylerine İlişkin Görüşlerine Yönelik Bulgular

\begin{tabular}{|c|c|c|c|c|c|c|}
\hline Çocuklarda Görülen Hastalıklar & 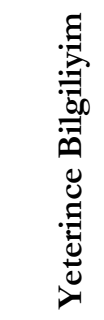 & & 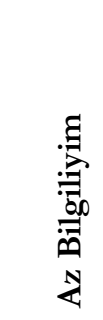 & & 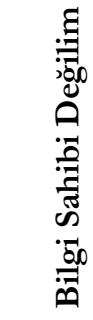 & \\
\hline & Ön & Son & Ön & Son & $\ddot{O} \mathrm{n}$ & Son \\
\hline & Uyg. & Uyg. & Uyg. & Uyg. & Uyg. & Uyg. \\
\hline Akdeniz Anemisi & 3 & 14 & 10 & 3 & 4 & \\
\hline Lösemi & 12 & 14 & 3 & 3 & 2 & \\
\hline Lenfoma & 8 & 13 & 6 & 4 & 3 & \\
\hline Hodgkin & 6 & 12 & 6 & 5 & 6 & \\
\hline Hemofili & 9 & 13 & 6 & 4 & 2 & \\
\hline Kronik Romatizmal Hastalıkları & 4 & 13 & 10 & 4 & 3 & \\
\hline Konjentinal Kalp Hastalikları & 4 & 10 & 9 & 7 & 4 & \\
\hline Diabet (Şeker) & 10 & 16 & 5 & 1 & 2 & \\
\hline Guatr & 8 & 16 & 6 & 1 & 3 & \\
\hline Kronik Enfeksiyon Hastalıkları & 8 & 12 & 5 & 5 & 4 & \\
\hline Hepatit A,B,C & 12 & 14 & 4 & 3 & 1 & \\
\hline Epilepsi & 7 & 12 & 7 & 5 & 3 & \\
\hline Kronik Böbrek Hastalıkları & 5 & 13 & 10 & 4 & 2 & \\
\hline Astım & 4 & 13 & 11 & 4 & 2 & \\
\hline Akdeniz Ateşi & 2 & 13 & 9 & 4 & 6 & \\
\hline Malign Hastalıklanı & 3 & 14 & 6 & 3 & 8 & \\
\hline Alerjik Hastalıkları & 6 & 13 & 9 & 4 & 2 & \\
\hline
\end{tabular}

Tablo 10'da görüldüğü gibi öğretmenlerin hastalık bilgisi konusuna ilişkin bilgi düzeyindeki yeterlilik düzeyleri hakkındaki görüşlerinin, ön uygulama-son uygulama bulguları incelendiğinde, olumlu yönde bir artış gösterdiği görülmektedir. Bu artş̧ bazı hastalıklarda yüksek düzeyde seyrederken (Akdeniz anemisi, kronik romatizmal hastalıklar, kalp hastalıkları, astım, akdeniz ateşi, malign hastalıklar vb), bazı hastalıklarda ise (Lösemi, hepatit) daha düşük düzeydedir. 
Öğretmenlerin hastane okullarında çocukların hastalıklarına yönelik karşılaşabilecekleri durumlara ilişkin mesleki yeterlilik düzeyleri hakkındaki görüşlerine yönelik bulgular Tablo 11'de verilmiştir.

Tablo 11. Öğretmenlerin Hastane Okullarında Cocukların Hastalıklarına Yönelik Karșlașabilecekleri Durumlara İlișkin Mesleki Yeterlilik Düzeyleri Hakkındaki Görüsslerine Yönelik Bulgular

\begin{tabular}{|c|c|c|c|c|c|c|}
\hline \multirow[t]{2}{*}{$\begin{array}{l}\text { Çocukların Hastalık Durumlarına } \\
\text { İlişkin Hastane Sınıflarında } \\
\text { Karşılaşılabileceği Durumlar }\end{array}$} & \multicolumn{2}{|c|}{ : } & \multicolumn{2}{|c|}{ 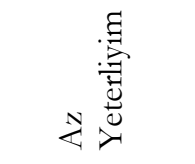 } & \multicolumn{2}{|l|}{ 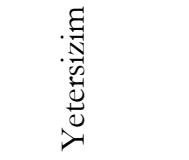 } \\
\hline & $\begin{array}{l}\ddot{O}_{\mathrm{n}} \\
\mathrm{Uyg} . \\
\mathrm{f}\end{array}$ & $\begin{array}{l}\text { Son } \\
\text { Uyg. } \\
\text { f }\end{array}$ & $\begin{array}{l}\text { Ön } \\
\text { Uyg. } \\
\text { f }\end{array}$ & $\begin{array}{l}\text { Son } \\
\text { Uyg. } \\
f\end{array}$ & $\begin{array}{l}\text { Ön } \\
\text { Uyg. } \\
\text { f }\end{array}$ & $\begin{array}{l}\text { Son } \\
\text { Uyg. } \\
\mathrm{f}\end{array}$ \\
\hline $\begin{array}{l}\text { Hemofili Hastası Olan Bir Çocukla } \\
\text { Çalışırken Dikkat Edilmesi } \\
\text { Gerekilen Hususlar Konusunda }\end{array}$ & 11 & 14 & 3 & 3 & 4 & \\
\hline $\begin{array}{l}\text { Konjentinal Kalp Hastalığı Olan Bir } \\
\text { Çocuğun Rahatsızlanması } \\
\text { Durumunda Acil Yapılması } \\
\text { Gerekenler Konusunda }\end{array}$ & 2 & 10 & 9 & 7 & 6 & \\
\hline $\begin{array}{l}\text { Şeker Hastası Bir Çocukla Çalışırken } \\
\text { Dikkat Edilmesi Gerekenler } \\
\text { Konusunda }\end{array}$ & 9 & 14 & 7 & 3 & 1 & \\
\hline $\begin{array}{l}\text { Şeker Hastası Bir Çocukla Çalışırken } \\
\text { Çocukta Meydana Gelen Şeker } \\
\text { Düzeyi Bozukluklarının Belirtilerini } \\
\text { Fark Etme Konusunda }\end{array}$ & 7 & 12 & 7 & 5 & 3 & \\
\hline $\begin{array}{l}\text { Enfeksiyon Hastalıklarından } \\
\text { Korunmak İçin Gereken Önlemleri } \\
\text { Alma Konusunda }\end{array}$ & 10 & 13 & 5 & 4 & 2 & \\
\hline $\begin{array}{l}\text { Epilepsi Nöbeti Geçiren Bir Çocuğa } \\
\text { İlk Müdahale Yapma Konusunda }\end{array}$ & 2 & 14 & 9 & 3 & 6 & \\
\hline $\begin{array}{l}\text { Alerjik Bir Hastalıktan Dolayı } \\
\text { Hastane De Yatan Bir Çocukla } \\
\text { Sinıfta Çalışırken Dikkat Edilmesi } \\
\text { Gerekenler Konusunda }\end{array}$ & 5 & 12 & 10 & 5 & 2 & \\
\hline
\end{tabular}

Tablo 11'e bakıldığında öğretmenlerin hastalık bilgisi konusuna ilişkin uygulama düzeyindeki yeterlilik düzeylerine ilişkin görüşlerinde, eğitim sonrası olumlu yönde bir artış görülmektedir. Bu artış bazı hastalıklar ile ilgili durumlarda yüksek düzeyde seyrederken (Konjentinal kalp hastalığı, epilepsi), bazı hastalıklarda ise (Hemofili, şeker, enfeksiyon hastalıkları) daha düşük düzeydedir.

Öğretmenlerin hastane okullarında iletişim boyutuna yönelik karşılaşabilecekleri durumlara ilişkin mesleki yeterlilik düzeyleri hakkındaki görüşlerine yönelik bulgular Tablo 12'de verilmiştir.

Tablo 12. Öğretmenlerin İletişim Boyutunda Hastane Sınıflarında Karşılaşabilecek Durumlara Hakkında Mesleki Yeterlilik Düzeylerine İlişkin Görüsslerine Yönelik Bulgular

\begin{tabular}{|c|c|c|c|c|c|c|}
\hline \multirow[t]{2}{*}{$\begin{array}{l}\text { İletişim Boyutunda Hastane Sınıflarında Karşılaşılabilecek } \\
\text { Durumlar }\end{array}$} & \multicolumn{2}{|c|}{ 牚 } & \multicolumn{2}{|c|}{ 头壱 } & \multicolumn{2}{|c|}{ 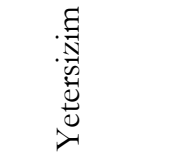 } \\
\hline & $\begin{array}{l}\text { Ön } \\
\text { Uyg. } \\
\mathrm{f}\end{array}$ & $\begin{array}{l}\text { Son } \\
\text { Uyg. } \\
\text { f }\end{array}$ & $\begin{array}{l}\text { Ön } \\
\text { Uyg. } \\
\mathrm{f}\end{array}$ & $\begin{array}{l}\text { Son } \\
\text { Uyg. } \\
\text { f }\end{array}$ & $\begin{array}{l}\text { Ön } \\
\text { Uyg. } \\
\mathrm{f}\end{array}$ & $\begin{array}{l}\text { Son } \\
\text { Uyg. } \\
\text { f }\end{array}$ \\
\hline Hasta Çocuklar İle Iletişim Kurma Konusunda & 15 & 17 & 2 & & & \\
\hline $\begin{array}{l}\text { Hasta Çocukla Yaşanabilecek Olası Bir İletişim Problemini } \\
\text { Çözme Konusunda }\end{array}$ & 14 & 16 & 3 & 1 & & \\
\hline Hasta Çocukların Aileleri İle İletişim Kurma Konusunda & 17 & 17 & & & & \\
\hline $\begin{array}{l}\text { Hasta Çocukların Aileleri İle Yaşanabilecek Olası Bir İletişim } \\
\text { Problemini Çözme Konusunda }\end{array}$ & 15 & 16 & 2 & 1 & & \\
\hline Hastane Personeli İle İletişim Kurma Konusunda & 15 & 17 & 2 & & & \\
\hline $\begin{array}{l}\text { Hastane Personeli İle Yaşanabilecek Olası Bir İletişim Problemini } \\
\text { Çözme Konusunda }\end{array}$ & 17 & 17 & & & & \\
\hline
\end{tabular}

Tablo 12'de görüldüğü gibi öğretmenlerin iletişim boyutu konusuna ilişkin yeterlilik düzeyleri hakkındaki görüşlerinde, ön uygulama-son uygulama bulguları incelendiğinde, genel olarak olumlu yönde bir artş görülmektedir. Bazı durumlarda ise ("Hasta Çocukların Aileleri İle İletişim Kurma Konusunda” ve "Hastane Personeli İle Yaşanabilecek Olası Bir İletişim Problemini Çözme Konusunda”) değişiklik olmamıştır. 
Öğretmenlerin hastane okullarında materyal geliştirme konusuna ilişkin mesleki yeterlilik düzeyleri hakkındaki görüşlerine yönelik bulgular Tablo 13 'te verilmiştir.

Tablo 13. Öğretmenlerin Materyal Geliştirme Konusuna İlişkin Mesleki Yeterlilik Düzeyleri Hakkındaki Görüşlerine Yönelik Bulgular

\begin{tabular}{|c|c|c|c|c|c|c|}
\hline \multirow[t]{3}{*}{ Materyalleri Geliştirme Konuları } & \multicolumn{2}{|c|}{ 胥 } & \multicolumn{2}{|c|}{ 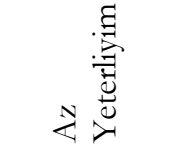 } & \multicolumn{2}{|c|}{ 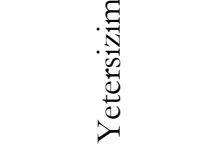 } \\
\hline & $\ddot{\text { Ön }}$ & Son & $\ddot{\mathrm{O} n}$ & Son & Ön & Son \\
\hline & Uyg. & Uyg. & Uyg. & Uyg. & Uyg. & Uyg. \\
\hline Çalışma Yaprakları Hazırlama & 12 & 15 & 2 & 2 & 3 & \\
\hline Kavram Haritası Oluşturma & 8 & 10 & 9 & 7 & & \\
\hline Dijital Materyal Geliştirme & 5 & 9 & 9 & 8 & 3 & \\
\hline Elle Materyal Geliştirme & 14 & 16 & 3 & 1 & & \\
\hline
\end{tabular}

Tabloda 13’te fark edildiği gibi öğretmenlerin materyal geliştirme konusuna ilişkin yeterlilik düzeyleri hakkındaki görüşlerinde, ön uygulama-son uygulama bulgulanı incelendiğinde, olumlu yönde bir artış görülmektedir.

Öğretmenlerin hastane okullarında strateji, yöntem ve teknikleri kullanma konusuna ilişkin mesleki yeterlilik düzeyleri hakkındaki görüşlerine yönelik bulgular Tablo 14’te verilmiştir.

Tablo 14. Öğretmenlerin Strateji, Yöntem ve Teknikleri Kullanma Konusuna İlişkin Mesleki Yeterlilik Düzeyleri Hakkındaki Görüşlerine Yönelik Bulgular

\begin{tabular}{|c|c|c|c|c|c|c|}
\hline \multirow[t]{2}{*}{ Strateji, Yöntem Ve Teknikler } & \multicolumn{2}{|c|}{ 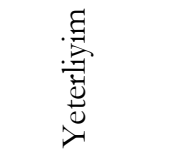 } & \multicolumn{2}{|c|}{ 之 } & \multicolumn{2}{|c|}{ 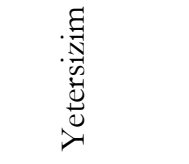 } \\
\hline & $\begin{array}{l}\ddot{O}_{\mathrm{n}} \\
\text { Uyg. } \\
\mathrm{f}\end{array}$ & $\begin{array}{l}\text { Son } \\
\text { Uyg. } \\
\text { f }\end{array}$ & $\begin{array}{l}\ddot{O}_{\mathrm{n}} \\
\text { Uyg. } \\
\mathrm{f}\end{array}$ & $\begin{array}{l}\text { Son } \\
\text { Uyg. } \\
\mathrm{f}\end{array}$ & $\begin{array}{c}\text { Ön } \\
\text { Uyg. } \\
\text { f }\end{array}$ & $\begin{array}{c}\text { Son } \\
\text { Uyg. } \\
\mathrm{f}\end{array}$ \\
\hline Buluş Yolu Öğrenme Stratejisi & 7 & 10 & 6 & 7 & 4 & \\
\hline Sunuş Yolu Öğrenme Stratejisi & 8 & 14 & 5 & 3 & 4 & \\
\hline Araştırma Ve Inceleme Yolu Stratejisi & 11 & 13 & 3 & 4 & 3 & \\
\hline Drama & 8 & 12 & 6 & 5 & 3 & \\
\hline Yapılandırmacilık & 9 & 11 & 3 & 6 & 5 & \\
\hline İnternet Temelli & 7 & 11 & 8 & 6 & 2 & \\
\hline Bireysel Öğretim & 12 & 15 & 3 & 2 & 2 & \\
\hline Eğitsel Oyunlar & 12 & 17 & 5 & & & \\
\hline
\end{tabular}

Tablo 14'te belirtildiği gibi hastane okullarında strateji, yöntem ve teknikleri kullanma konusuna ilişkin görüşlerinde, ön uygulama-son uygulama bulguları incelendiğinde, olumlu yönde bir artış görülmektedir.

Öğretmenlerin hastane okullarında ölçme-değerlendirme tekniklerini hazırlama ve kullanma konusuna ilişkin mesleki yeterlilik düzeyleri hakkındaki görüşlerine yönelik bulgular Tablo 15 ’te verilmiştir.

Tablo 15. Öğretmenlerin Ölçme-Değerlendirme Tekniklerini Hazırlama ve Kullanma Konusu Hakkında Mesleki Yeterlilik Düzeylerine İlişkin Görüşlerine Yönelik Bulgular

Ölçme-Değerlendirme Teknikleri Hazırlama ve Kullanma Durumları

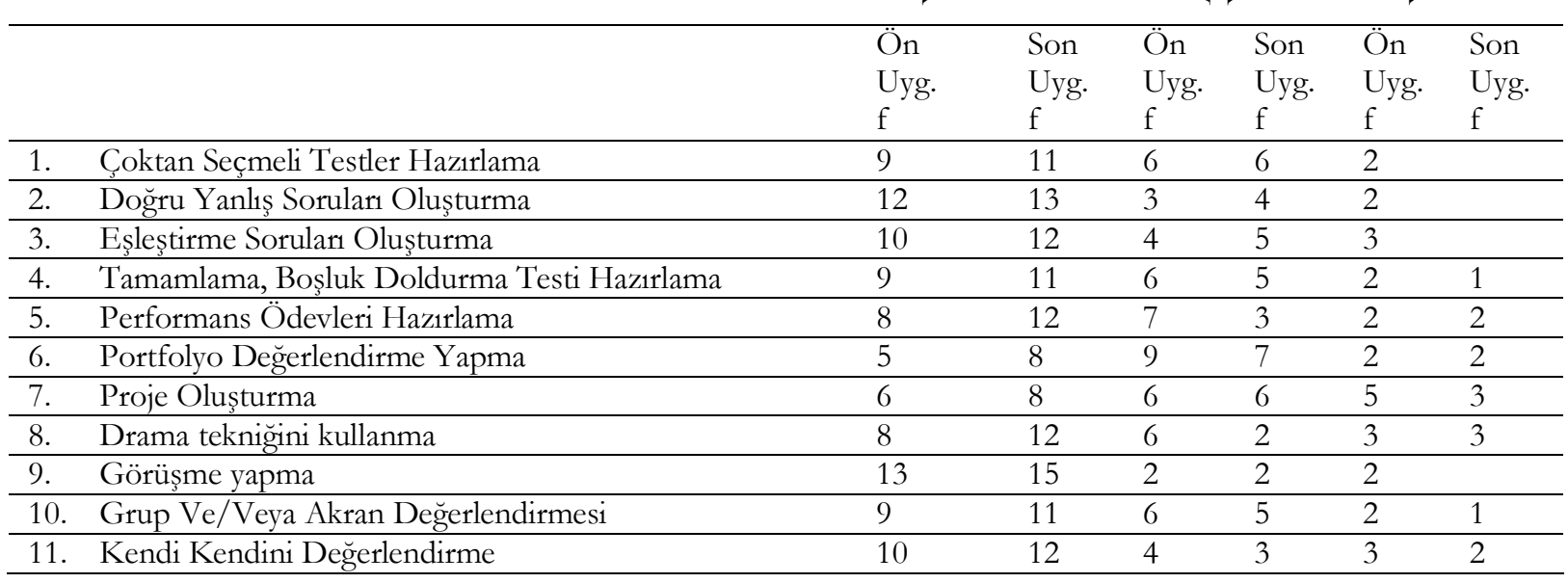


Tablo 15 ’te ifade edildiği gibi öğretmenlerin ölçme-değerlendirme tekniklerini hazırlama ve kullanma konusuna ilişkin yeterlilik düzeylerine ilişkin görüşlerinin, ön uygulama-son uygulama bulguları incelendiğinde, olumlu yönde değiştiği görülmektedir.

Hizmet içi eğitime katılan öğretmenlerin, genel olarak bakıldığında, hastalık bilgisi, iletişim, ölçmedeğerlendirme ve öğrenme-öğretme sürecine yönelik mesleki yeterlilik düzeylerine ilişkin görüşlerinde, eğitim öncesi ve sonrasına göre, olumlu yönde bir artış görülmektedir. Bu artış hastalık bilgisi konusunda yüksek düzeyde seyrederken, iletişim, öğrenme-öğretme durumu ve ölçme-değerlendirme konusunda daha düşük düzeydedir.

\subsection{Araştırmanın Üçüncü Alt Problemine Yönelik Bulgular}

Hizmet içi eğitim programının öğretmenlere sağladığı katkılara yönelik bulgular Tablo 16'da verilmiştir.

Tablo 16. Eğitimin Öğretmenlere Sağladığı Katkılara İlişkin Betimsel İstatistikler (n:17)

\begin{tabular}{lll}
\hline Sağlanan Katkı & $\mathrm{f}$ & $\%$ \\
\hline Yeni Kazanımlar edinme & 17 & 100 \\
Bir araya gelme şansı yakalama & 9 & 52,9 \\
Sorunlarımızı dile getirme şansı yakalama & 7 & 41.2 \\
Önemsendiğimizi hissetme & 5 & 29,4 \\
\hline
\end{tabular}

Tablo 16'da görüldüğü gibi hastane sınıfi öğretmenleri eğitimin katkılarına yönelik sorulan soruya çoğunlukla, yeni kazanımlar elde etme, bir araya gelme şansı yakalama şeklinde cevap vermişlerdir.

Öğretmenlerin eğitim ile ilgili olumlu görüşlerine yönelik bulgular Tablo 17'de verilmiştir.

Tablo 17. Öğretmenlerin Eğitime Yönelik Olumlu Görüşlerine İlişkin Betimsel İstatistikler (n:17)

\begin{tabular}{lll}
\hline Olumlu Düşünceler & $\mathrm{f}$ & $\%$ \\
\hline Bilgilerin güncellenmesi & 17 & 100 \\
Bir araya gelme şansı yakalama & 9 & 52,9 \\
Sorunlarımızı dile getirme şansı yakalama & 7 & 41,8 \\
Önemsendiğimizi hissetme & 5 & 29,4 \\
Tecrübelerimiz ile yeni bilgilerimizi birleştirme şansı yakalama & 4 & 23,5 \\
Yeni kazanımların hastane uygulamalarında yararlı olacağına inanma & 4 & 23,5 \\
\hline
\end{tabular}

Tablo 17'de görüldüğü gibi hastane sınıfı öğretmenleri eğitim ile ilgili olumlu görüşlerine yönelik sorulan soruya çoğunlukla, bilgilerin güncellenmesi ve bir araya gelme şansı yakalama şeklinde cevap vermişlerdir.

Öğretmenlerin eğitim ile ilgili olumsuz görüşlerine yönelik bulgular Tablo 18 ’te verilmiştir.

Tablo 18. Öğretmenlerin Eğitime Yönelik Olumsuz Görüşlerine İlişkin Betimsel İstatistikler (n:17)

\begin{tabular}{lll}
\hline Olumsuz Düşünceler & $\mathrm{f}$ & $\%$ \\
\hline Zamanın Kısa Olması & 8 & 47,1 \\
Yönetimsel Sorunlar & 7 & 41,2
\end{tabular}

Tablo 18'te ifade edildiği gibi hastane sınıfı öğretmenleri, zaman kısa olması ve yönetimsel sorunlar şeklinde eğitimle ilgili olumsuz görüşlerini belirtmişlerdir.

\subsection{Araştırmanın Dördüncü Alt Problemine Yönelik Bulgular}

Bu bölümde hizmet içi eğitim programının, uygulama sürecindeki etkililiğine ilişkin öğretmen düşünceleri neler olduğuna yönelik bulgulara yer verilmiştir.

Hizmet içi eğitim programının, öğretmenlere 2013-2014 eğitim uygulamalarında sağladığı katkılara yönelik bulgular Tablo 19'da verilmiştir.

Tablo 19. Eğitimin Öğretmenlere Sağladığı Katkılara İlişkin Betimsel İstatistikler (n:5)

\begin{tabular}{lcc}
\hline Eğitimin Sağladığı Katkılar & f & $\mathbf{0}$ \\
\hline Hastalık Bilgisi konusunda ihtiyaç duyulan bilgilerin kazanma & 5 & 100 \\
Hastalık konusunda öğrenilen pratik bilgileri uygulamada kullanma & 5 & 100 \\
Hasta çocuklarla daha iyi iletişim kurmayı sağlama & 5 & 100 \\
Hasta çocukların aileleri ile daha iyi iletişim kurmayı sağlama & 5 & 100 \\
Hastane personeli ile daha iyi iletişim kurmayı sağlama & 5 & 100 \\
Eğitim materyali geliştirme & 3 & 60 \\
Yatak başı eğitim süreci planlamada rehberlik etme & 2 & 40 \\
Süreç değerlendirmeye yönelik materyal geliştirme & 2 & 40 \\
Öğretmenlik performansını ölçme & 1 & 20 \\
\hline
\end{tabular}


Tablo 19'da görüldüğü gibi hastane sınıfi öğretmenleri eğitimin katkılarına yönelik sorulan soruya çoğunlukla, hastalık bilgisi konusunda ihtiyaç duyulan bilgilerin kazanma, hastalık konusunda öğrenilen pratik bilgileri uygulamada kullanma, hasta çocuklarla daha iyi iletişim kurmayı sağlama, hasta çocukların aileleri ile daha iyi iletişim kurmayı sağlama, hastane personeli ile daha iyi iletişim kurmayı sağlama ve eğitim materyali geliştirme şeklinde cevap vermişlerdir.

Eğitimin hastane okullarında karşılaşılan problemlerin çözümüne sağladığı katkılara yönelik bulgular Tablo 20'de verilmiştir.

Tablo 20. Eğitimin Öğretmenlerin Karşılaştıkları Problemlerin Çözümüne Sağladığı Katkılara İlişkin Betimsel İstatistikler (n:5)

\begin{tabular}{lcc} 
(n:5) & f & \% \\
\hline Ĕğitimin Problemlerin Çözümüne Sağladı̆̆ı Katkılar & 5 & 100 \\
\hline Öğrenci ile yaşanan problemlerin çözümünde rehberlik etme & 4 & 80 \\
Ĕgitim planlamalarında yaşanan problemlerin çözümünde rehberlik etme & 4 & 80 \\
Hastane personeli ile yaşanan problemlerin en aza indirilmesine katkı sağlama & 2 & 40 \\
Eldeki imkânlar doğrultusunda eğitim materyali geliştirme konusunda farkındalık sağlama & 2 \\
\hline
\end{tabular}

Tablo 20'de görüldüğü gibi hastane sınıfi öğretmenleri eğitimin karşılaştıkları problemlerin çözümüne sağladığ1 katkılar ile ilgili görüşlerine yönelik sorulan soruya çoğunlukla, öğrenci ile yaşanan problemlerin çözümünde rehberlik etme, eğitim planlamalarında yaşanan problemlerin çözümünde rehberlik etme ve hastane personeli ile yaşanan problemlerin en aza indirilmesine katkı sağlama şeklinde cevap vermişlerdir.

Eğitimin öğretmenlerin mesleki gelişimine sağladığ1 katkılara yönelik bulgular Tablo 21'de verilmiştir.

Tablo 21. Eğitimin Öğretmenlerin Mesleki Gelişimlerine Sağladığ1 Katkılara İlişkin Betimsel İstatistikler (n:5)

\begin{tabular}{lll}
\hline Eğitimin Öğretmenlerin Mesleki Gelişimine Sağladı̆̆ı Katkılar & f & $\mathbf{\%}$ \\
\hline Mesleki açıdan eksik bilgilerin tamamlanması & 5 & 100 \\
Daha fazla araştırma yapma yönünden motivasyon sağlaması & 4 & 80 \\
Yapılan işin öneminin bir kez daha farkına varılması & 3 & 60 \\
Hasta ögrenciler ve aileleri ile iletişim kurma & 2 & 40 \\
\hline
\end{tabular}

Tablo 21'de ifade edildiği gibi hastane sınıfı öğretmenleri, eğitimin mesleki gelişimlerine sağladığı katkılara ilişkin olarak, mesleki açıdan eksik bilgilerin tamamlanması daha fazla araştırma yapma yönünden motivasyon sağlaması ve yapılan işin öneminin bir kez daha farkına varılması şeklinde eğitimle ilgili görüşlerini belirtmişlerdir.

Öğretmenlere, "Bu eğitim yeniden veriliyor olsa neler yapılmasını isterdiniz?” sorusu sorulmuş ve alınan cevaplar Tablo 22'de verilmiştir.

Tablo 22. Öğretmenlerin Eğitim Sürecine Yönelik Görüşlerine İlişkin Betimsel İstatistikler (n:5)

\begin{tabular}{lcc} 
Tablo 22. Oğretmenlerin Eğtim Sürecine Yönelik Goruşlerine llişkin Betimsel İstatistikler (n:5) & f & $\mathbf{\%}$ \\
\hline Eğitim Sürecine Yönelik Öneriler & 5 & 100 \\
\hline Sürenin daha uzun tutulması & 5 & 100 \\
Süreçte daha fazla uygulamaya yer verilmesi & 4 & 80 \\
Eğitimde daha fazla materyale yer verilmesi & 4 & 80 \\
Eğitimlerin rutine bindirilmesi & 3 & 60 \\
Eğitimlerin yayın haline getirilmesi & 2 & 40 \\
Hastane okullart ile ilgili yasal mevzuatı bilen bir bakanlık yetkilisinin bu tür eğitimlere katılması & 1 & 20 \\
Eğitimin uygulamalı olarak hastane okullarında verilmesi & 20
\end{tabular}

Tablo 22'de görüldüğü gibi öğretmenler çoğunlukla, eğitim sürecine yönelik önerilerine ilişkin görüşlerini, sürenin daha uzun tutulması, süreçte daha fazla uygulamaya yer verilmesi, eğitimde daha fazla materyale yer verilmesi, eğitimlerin rutine bindirilmesi ve eğitimlerin yayın haline getirilmesi şeklinde ifade etmişlerdir.

\section{TARTIŞMA ve SONUÇ}

Hizmet içi eğitime katılan öğretmenlerin, hastalık bilgisi, iletişim, ölçme-değerlendirme ve öğrenmeöğretme sürecine yönelik akademik başarı puanları ve mesleki yeterlilik düzeylerine ilişkin görüşleri eğitim sonrası olumlu yönde artış göstermiştir. Bu konular öğretmenlerin eğitim ihtiyaçları doğrultusunda belirlenmiştir ve öğretmenler kendileri bu konularda eğitime ihtiyaç duyduklarını ifade etmişlerdir. Öğretmenlerin eğitim ihtiyaçları doğrultusunda hazırlanan eğitimin, öğretmenlerin akademik başarısını ve mesleki yeterlilik düzeylerine ilişkin görüşlerini olumlu yönde etkilemesi beklenen sonuç olarak görülmektedir. Ayrıca bu sonuç uygulanan eğitimin etkili olduğunun bir göstergesi olarak kabul edilebilir. Mezun oldukları üniversitede ve daha sonra meslek yaşamlannda bu konuda eğitim almamış öğretmenlerin, ihtiyaç duyduklanı konularda eğitim almalarının bu başarıya katkı sağladığı düşünülmektedir. Eğitim sonrası öğretmen görüşleri de eğitimin akademik gelişimlerine katkı sağladığı yönündedir. Eğitim sırasındaki ifadeleri ise yeni bilgiler 
öğrendikleri ve mesleki gelişimlerine katkı sağladığı şeklindedir. Meslek hayatını sürdüren öğretmenlerin, yeni bilgi teknolojilerine uyum sağlamalarında ve kendilerini sürekli geliştirmelerinde, hizmet içi eğitim programlarının büyük katkısı olduğu düşünülmektedir. Dolunay (2002), García (2004), Gökdere \& Çepni (2003), Kayabaş (2008), Uçar \& İpek (2006), Uşun \& Cömert’in (2003) yaptıkları çalışmalarda, hizmet içi eğitimin gerekliliğine ve önemine vurgu yapmışlardır.

Genel olarak eğitim programına ilişkin öğretmen görüşlerine bakıldığında, eğitimin kendileri için çok faydalı olduğu, olumlu geçtiği, yeni bilgiler kazandıkları şeklinde düşünceleri oldukları görülmektedir. Bu öğretmen görüşlerini, gerek akademik başarı testi, gerekse mesleki yeterlilik düzeylerine ilişkin görüş anketi sonuçları desteklemektedir. Hizmet içi eğitim programlarının, öğretmenlerin kendilerini geliştirmelerinde, büyük katkısı olduğu düşünülmektedir (Dolunay, 2002; García, 2004; Gökdere \& Çepni 2003). Öğretmenlerin hizmet içi eğitim programlanının öneminin farkında olmaları, ifade ettikleri olumlu görüşlerin nedeni olarak varsayılabilir.

Araştırma bulgularına bakıldığında hizmet içi eğitim programının öğretmenlere, mesleki açıdan ihtiyaç duyulan bilgilerin kazanma ve bu bilgileri uygulamada kullanma, hasta çocuklar, aileleri ve hastane personeli ile daha iyi iletişim kurmayı sağlama ve eğitim materyali geliştirme konularında katkı sağladığı görülmektedir. Ayrıca gerçekleştirilen hizmet içi eğitim programının, öğrenci ve hastane personeli ile yaşanan problemlerin çözüm sürecine olumlu etki yaptığ1 görülmüştür. Eğitim içeriğinin, öğretmenlerin eğitim ihtiyaçları ve istekleri doğrultusunda oluşturulmasının bu olumlu sonuçların çıkmasının ana nedeni olarak varsayılabilir. Hastane okullarında çalışan öğretmenlerin, gerek mezun oldukları üniversitede gerekse meslek yaşamlarında bu konularda yeterli eğitim almadıkları görülmektedir. Bu nedenle öğretmenlerin eğitim ihtiyaçları doğrultusunda geliştirilen hizmet içi eğitim programının olumlu katkı sağlaması beklenen bir sonuç olarak görülebilir. Ayrıca her geçen gün toplumsal, kültürel, ekonomik, siyasal, teknolojik alanlara ait bilgilerde hızlı ve önemli değişmeler olmaktadır. Her alandaki bu hızlı değişmeler, meslekler, iş tanımlanı, gereksinim duyulan beceriler gibi toplumsal yaşamın birçok alanında ihtiyaç duyulan insan niteliklerinin, sürekli olarak değişmesini zorunlu kılmıştır. Bunun sonucu olarak öğretmenlerin kendilerini sürekli geliştirmeleri ve yeni bilgi teknolojilerine uyum sağlamaları gerekmektedir. Hizmet içi eğitim programlarının ise öğretmenlerin, yeni bilgi teknolojilerine uyum sağlamalarında ve kendilerini sürekli geliştirmelerinde, büyük katkısı olduğu düşünülmektedir. Yapılan çalışmalar da bu fikri destekler nitelikte olup, hizmet içi eğitim programlanının gerekliliğine ve önemine vurgulamışlardır (Dolunay, 2002; García, 2004; Gökdere \& Çepni 2003; Kayabaş, 2008). Sonuç olarak bu tür hizmet içi eğitim programlarının geliştirilmesi ve uygulanması, öğretmenlerin eğitim ihtiyaçlanının karşılanması ve yeni bilgi teknolojilerine uyum sağlamaları adına önemli görülmektedir.

Öğretmenler, eğitim sürecinin daha uzun tutulması, süreçte daha fazla uygulamaya ve materyale yer verilmesi, eğitimlerin rutine bindirilmesi ve eğitimlerin yayın haline getirilmesi konularında önerilerde bulunmuşlardır. Öğretmenlerin bu önerilerde bulunmalarında, geliştirilen ve uygulanan hizmet içi eğitim programının gerek öğretmenlerin mesleki gelişimlerine ve mevcut problemlerin çözümüne katkı sağlamasının gerekse interaktif geçmesinin etkisi olduğu düşünülmektedir. Öğretmenlerin, hizmet içi eğitim programı sürecinde yeni ve pratik bilgiler kazanmaları, bilgi ve deneyimlerini paylaşma şansı yakalamaları, bu eğitimin sürecinin daha uzun süreler için planlanması ve daha fazla uygulama içermesini istemelerinin nedeni olarak görülebilir.

Sonuç olarak hizmet içi eğitime katılan öğretmenlerin, hastalık bilgisi, iletişim, ölçme-değerlendirme ve öğrenme-öğretme sürecine yönelik mesleki yeterlilik algılarında ve akademik başarı puanlarında, eğitim öncesi ve sonrasına göre, olumlu yönde bir artış görülmektedir. Bu sonuç, gerçekleştirilen hizmet içi eğitim programının öğretmenlerin gelişimleri için etkili olduğunun bir göstergesi olarak düşünülebilir. Meslek hayatını sürdüren öğretmenlerin, yeni bilgi teknolojilerine uyum sağlamalarında ve kendilerini sürekli geliştirmelerinde, hizmet içi eğitim programlarının büyük katkısı olduğu ifade eden birçok çalışma vardır. García (2004), Uçar ve İpek (2006) \& Kayabaş (2008) yaptıkları çalışmalarda, hizmet içi eğitimin gerekliliğine ve önemine 
vurgulamışlardır. Bundan dolayı bu tür hizmet içi eğitim programlarının devam ettirilmesi, öğretmenlerin eğitim ihtiyaçlarının karşılamaları adına önemli görülmektedir.

Aşağıda araştırma sonuçlarına yer verilmiştir.

- Uygulanan hizmet içi eğitim programının, hastane okulu öğretmenlerinin, hastalık bilgisi, iletişim, öğrenme-öğretme süreci, ölçme-değerlendirme konusuna yönelik akademik başarılarını arttırdığı sonucuna ulaşılmıştır.

- Uygulanan hizmet içi eğitim programı sonrası öğretmenlerin, hastalık bilgisi, iletişim, öğrenme-öğretme süreci ve ölçme-değerlendirme konusunda yeterlilik düzeylerine ilişkin görüşlerinin, olumlu yönde değiştiği sonucuna ulaşılmıştır.

- Uygulanan hizmet içi eğitim programının öğretmenlere, yeni kazanımlar edinme, biraya gelme şansı yakalama, sorunlarımızı dile getirme şansı yakalama, önemsendiğini hissetme yönünde katkı sağladığ1 sonucuna ulaşılmıştır.

- Uygulanan hizmet içi eğitim programının öğretmenlere, bilgilerin güncellenmesi, biraya gelme şansı yakalama, sorunlarımızı dile getirme şansı yakalama, önemsendiğini hissetme, tecrübeler ile yeni bilgileri birleştirme şansı yakalama, yeni kazanımların uygulamada yararlı olma konularında olumlu katkıları olduğu yargısına ulaşılmıştır.

- Uygulanan hizmet içi eğitim programının öğretmenlere, hastalık bilgisi konusunda ihtiyaç duyulan bilgilerin kazanma, hastalık konusunda öğrenilen pratik bilgileri uygulamada kullanma, hasta çocuk, aile ve hastane personelleri ile daha iyi iletişim kurmayı sağlama ve eğitim materyali geliştirme açısından katkı sağladığı sonucuna ulaşılmışır.

- Uygulanan hizmet içi eğitim programının öğretmenlere, öğrenci ile ve eğitim planlamalarında yaşanan problemlerin çözümünde rehberlik etme ve hastane personeli ile yaşanan problemlerin en aza indirilmesi konularında olumlu katkıları olduğu yargısına ulaşılmıştır.

- Hizmet içi eğitim programının, mesleki açıdan eksik bilgilerin tamamlanması daha fazla araştırma yapma yönünden motivasyon sağlaması ve yapılan işin öneminin farkına varılması konularında öğretmenlerin mesleki gelişimine olumlu katkı sağladığı sonucuna varılmıştır.

- Uygulanan hizmet içi eğitim programı süresinin daha uzun tutulması, süreçte daha fazla uygulamaya ve materyale yer verilmesi, eğitimlerin rutine bindirilmesi ve yayın haline getirilmesi gerekliliği sonucuna ulașilmıștır.

\section{5. Öneriler}

- Hizmet içi eğitime katılan öğretmenlerin, hastalık bilgisi, iletişim, ölçme-değerlendirme ve öğrenmeöğretme sürecine yönelik mesleki yeterlilik algılarında ve akademik başarı puanlarında, eğitim öncesi ve sonrasına göre, olumlu yönde bir artış görülmektedir. Öğretmenlerin mesleki gelişimine faydalı olduğu düşünülen bu çalışmada olduğu gibi zaman zaman öğretmenlerin eğitim ihtiyaçları belirlenerek periyodik zamanlarda hizmet içi eğitim programları düzenlenmesi önerilmektedir.

- Hastane okullarının daha çok tanınması ve olası problemlerine çözüm üretebilmek için gerek betimsel gerekse deneysel araştırma yapılması önerilmektedir.

- Bu çalışmada, gerek bütçe yetersizliği gerekse resmi izin alınması konularında yaşanan sıkıntılardan dolayı sadece Ankara ilinde görev yapan öğretmenlere bir haftalık hizmet içi eğitim verilebilmiştir. Tüm öğretmenleri kapsayan ve daha fazla uygulama içeren eğitim programlarının geliştirilmesini hedefleyen araştırmalar planlanması önerilmektedir.

- Yapılan çalışma sürecinde hastane okullarında görev yapan öğretmenlerin büyük bir çoğunluğunun sınıf öğretmenliği mezunu oldukları görülmektedir. Eğitim fakülteleri ile iletişim kurularak sınıf öğretmenliği bölümü dersleri arasına hastane okulları ile ilgili dersler konulabilir. Hatta öğrencilerin bu okullarda staj yapması sağlanabilir. 
- Her hastane okulu, iki norm kadroya sahiptir. Yalnız bulundukları hastanenin yapısına bağlı olarak, öğrenci sayısı değişkenlik göstermektedir. Okulların öğrenci sayısı dikkate alınarak norm kadrolar tekrar düzenlenebilir.

- Türkiye genelinde hastane sınıflarında çalışan tüm öğretmenleri kapsayan bir e-posta grubunun oluşturulması, öğretmenlerin online iletişim kurmalarına ve deneyimlerini paylaşmalarına destek sağlayabilir.

- Yapılan bu araştırma süreci boyunca, Milli Ĕ̆itim Bakanlı̆̆1 ile sürekli irtibat halinde bulunulmuştur. Bu iletişim araştırma sürecine olumlu katkı sağlamıştır. Araştırmacıların, yapacakları çalışmalarda Milli Ë̆itim Bakanlı̆̆ı ile iletişim kurmaları önerilmektedir.

\section{KAYNAKÇA}

Aktaş, S. (1992). Hasta Cocuk ve Ailelerinin Sağlık Personeli ile Illetişim Boyutlar. Yüksek Lisans Tezi, Ana-Çocuk Sağlı̆̆1, İstanbul.

Baykoç, N. (2006). Hastanede Cocuk ve Genç. Ankara: Gazi Kitapevi.

Bowling, A. (2002). Research Methods in Health: Investigating Health and Health Services. Philadelphia, PA: McGrawHill House.

Butler, RW. \& Mulhern, RK. (2005). Neurocognitive Interventions for Children and Adolescents Surviving Cancer. J. Pediatr. Psychol, 30, 65-78.

Büyüköztürk, Ş. (2007). Sosyal Bilimler için Veri Analiz̨i El Kitabı. Ankara: Pegem A Yayıncılık.

Dolunay, A.B. (2002). Farklı Lise Öğretmenleri Üzerinde Hizmet İçi Eğitim İhtiyacı. Ankara Üniversitesi Tıp Fakiültesi Mecmuasi, Ankara, 55(1), 51-62.

Eiser, C., Hill JJ. \& Vance YH (2002). Examining The Psychological Consequences Of Surviving Childhood Cancer: Systematic Review As A Research Method İn Pediatric Psychology. Journal Of Pediatric Psychology. 25(6), 449-460.

Elçigil, A. (2007). Kanserli çocuk okula gidebilir mi? Ç.Ü. Hemşirelik Yükesekokulu Dergisi, 11 (2).

Erdogan, A. \& Karaman, G. M. (2008). Kronik Ve Ölümcül Hastalı̆̆ı Olan Çocuk ve Ergenlerde Ruhsal Sorunların Tanınması ve Yönetilmesi. Anadolu Psikiyatri Dergisi, 9, 244- 252.

Fazlıŏ̆lu, K., Hocaoğlu, Ç. \& Sönmez, M. F. (2010). Çocukluk Çağ1 Epilepsisinin Aileye Etkisi. Psikiyatride Güncel Yaklaşımlar, 2(2), 190-205

Garcia, R.A. (2004). The Difficult Relationship Between Theory and Practice In an In-Service Course For Science Teachers. Int. J. Science Education, 10(26), 1223-1245.

Gökdere, M. \& Çepni, S. (2003). Üstün Yetenekli Öğrencilerin Fen Öğretmenlerinin Eğitimine Yönelik Bir Model Önerisi. The Turkish Online Journal of Educational Technology, 3 (2).

Gönener, D. \& Görak, G. (2009). Okul Yaş Grubu Çocukların Hastane ve Hastalı̆̆1 ile İlgili Bilgilendirme Durumlarının Endişe Kaynakları ile Etkileşimi. Gaz̧iantep Tıp Dergisi. 15 (1), 41-48.

Işıktekiner, S. \& Altun, S. (2011). Hastane Okullarındaki Sorunlar ve Yaşantılar, Eğgitim ve Bilim, $36,161$.

Kamışlı, H., Yelken, Yanpar, T. \& Akay, C. (2014). Hastane Okullarının Mevcut Durumuna İlişkin Öğretmen Görüşleri. Yüzüncü Yal Üniversitesi Eğitim Fakültesi Dergisi, 10 (1), 321-351.

Karasar, N. (2000). Bilimsel Araştırma Yöntemleri. Ankara: Nobel Yayın Dağ1tım.

Kayabaş, Y. (2008). Öğretmenlerin Hizmet İçi Eğitimde Yetiştirilmesinin Önemi ve Esasları. Türkiye Sosyal Arasttrmalar Dergisi, 2(12), 9-32

Krueger, R.A. (1994). Focus Groups: A Practical Guide For Applied Research. London: SAGE.

Lähteenmäki PM., Huostila J., Hinkka \& S, Salmi TT. (2002). Childhood Cancer Patients At School. European Journal Of Cancer, 38( 9), 1227-1240.

Mayring, P. (1996). Nitel Sosyal Araștırmaya Girişs. (Çev: A. Gümüş \& M., S. Durgun). Adana: Baki Kitabevi.

Miles, M. \& Huberman, A. (1994). Qualitative Data Analysis: An Expanded Source Book (2nd Ed.), Thousand Oakes: Sage Publications.

Ness, KK., Mertens, AC. \& Hudson, MM. (2005). Limitations On Physical Performance and Daily Activities Among Long-Term Survivors Of Childhood Cancer. Annals Of Internal Medicine, 143, 639-647.

Patenaude, AF. \& Kupst MJ. (2005). Psychosocial Functioning in Pediatric. Journal of Pediatric Psychology. 30, 927.

Prevatt, F., Heffer, RW. \& Lowe, PA. (2000). A Review of School Reintegration Programs for Children with Cancer. Journal of School Psychology, 38 (5), 447-467.

Uçar, R. \& C. İpek. (2006). İlköğretim Okullarında Görev Yapan Yönetici ve Öğretmenlerin MEB Hizmet İçi Eğitim Uygulamalarına İlişkin Görüşleri. Yüzüncü Yul Üniversitesi, Eğitim Fakültesi Dergisi, 3 (1), 34-53. 
Uşun, S. ve Cömert, R. (2003) Okul Öncesi Öğretmenlerde Hizmet İçi Eğitim İhtiyac1. G.Ü., Gaz̧i Eğitim Fakëlltesi Dergisi, 23 (2), 125-138.

Vance, YH. \& Eiser, C. (2002). The School Experience of The Child with Cancer. Child: Care, Health \& Development. 28,1,5-19.

Vannatta, K., Gartstein, MA. \& Short, A. (1998). A Controlled Study of Peer Relationships of Children Surviving Brain Tumors: Teacher, Peer, and Self Ratings. Journal Of Pediatric Psychology. 23(5), 279-287.

\section{Citation Information}

Kamışlı, H., Yanpar Yelken, T. \& Akay, C. (2016) Hastane Okullarına Yönelik Geliştirilen Eğitici Eğitimi Programının Öğretmenler Üzerindeki Etkisi. Dicle Üniversitesi Ziya Gökałp Eğitim Fakïltesi Dergisi, 28, 141-155. 